\title{
AEROMAGNETIC AND GEOLOGIC MAP OF NORTHERN BELTRAMI AND SOUTHERN LAKE OF THE WOODS COUNTIES, MINNESOTA By
}

J. L. Meuschke, K. G. Books, John R. Henderson, Jr., and G. M. Schwartz

\author{
GEOPHYSICAL INVESTIGATIONS \\ MAP GP 129
}

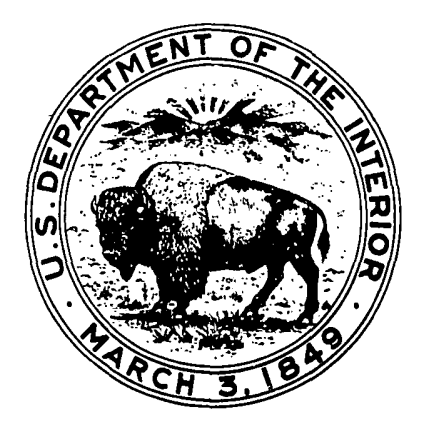

PUBLISHED BY THE U. S. GEOLOGICAL SURVEY 